\title{
Fotografías del Puente Colgante de Santa Fe. Una mirada desde la ingeniería
}

Muestra de imágenes fotográficas, reseña y antecedentes sobre los aspectos técnicos, tecnológicos y constructivos del Puente Colgante de Santa Fe.

Proyecto de Voluntariado Universitario «Puente Colgante: Nuestra Identidad»

de la Universidad Tecnológica Nacional, Facultad Regional Santa Fe

Carolina Anabel Bravi

Facultad de Arquitectura, Diseño y Urbanismo,

Universidad Nacional del Litoral

La «Muestra de imágenes fotográficas, reseña y antecedentes sobre los aspectos técnicos, tecnológicos y constructivos del Puente Colgante de Santa Fe» fue presentada por la Universidad Tecnológica Nacional, Facultad Regional Santa Fe, como parte del evento organizado por el gobierno municipal «La noche de los museos. Edición 20I4", en conmemoración del aniversario de la fundación de la ciudad. La exposición condensó una parte del trabajo realizado por docentes y estudiantes de la universidad en el marco del Programa de Voluntariado Universitario «Puente Colgante: Nuestra Identidad». Del mismo participaron cuatro alumnos avanzados de ingeniería civil, Nicolás Albanesi, Gonzalo Cior- ciari, Florencia Coria y Natalia Lagger; y tres coordinadores, el arquitecto Rubén Grether y las licenciadas Mariana Rabaini y Marta Castellaro.

El Puente Colgante de Santa Fe, ubicado sobre la laguna Setúbal, fue inaugurado en 1928 para cumplir las funciones de medio de comunicación vial y acueducto para transportar el agua, tomada del río Colastiné, hacia la Planta Potabilizadora de la ciudad de Santa Fe. Este puente colgante semirrígido, de tres tramos y con dos pilares, colapsó en 1983 como consecuencia de una inundación cayendo una de sus antenas. Luego de esto permaneció inutilizable hasta 2002 año en que fue reconstruido. Algunas de sus partes recuperadas del tramo caído 
fueron vendidas y las que pudieron ser conservadas, se encuentran hoy sin uso y $\sin$ un destino cierto.

Este proyecto partió entonces del relevamiento y la constatación del estado de estos restos y propuso la reutilización de los mismos (sin intervenirlos) a través de un concurso de ideas para la realización de esculturas con el objetivo de recuperar y revalorizar los componentes originales del puente (actualmente depositados en el puerto local) rescatando su valor patrimonial desde una mirada tecnológica y cultural. Junto a esta propuesta se desarrolló una investigación histórica orientada a recopilar información proveniente de diversas fuentes, como archivos personales y de distintas instituciones, y entrevistas a personas que participaron en los trabajos de mantenimiento y reconstrucción, entre otros. En esta búsqueda las imágenes se convirtieron en documentos centrales que permitieron testimoniar las situaciones relacionadas con la vida del puente, por ejemplo su construcción y reconstrucción, así como con la valoración social que el mismo fue adquiriendo con el paso del tiempo. Desde su identificación como emblema de progreso y modernidad de toda la ciudad, hasta la documentación de las distintas tareas llevadas a cabo para su rehabilitación (el traslado de la nueva antena en una embarcación, la reparación de la cámara de anclaje de los cables de acero, la prueba de carga, etc.), todas estas facetas fueron exhibidas en las imágenes.

Las cuarenta fotografías seleccionadas para la muestra, de un total de ciento cincuenta relevadas, fueron acompañadas por una línea histórica donde se marcaron los distintos momentos claves de su historia, comenzando con su construcción en la década del veinte, pasando por la época de esplendor, su caída y la posterior reconstrucción. En la selección de imágenes es posible reconocer la presencia de una mirada particular que destaca aspectos escasamente valorados por las investigaciones precedentes. Este enfoque, basado en una observación detallada del objeto, se focaliza en los materiales, en el modo en que éstos son puestos en la obra, en las máquinas y equipamientos necesarios para realizar los trabajos y en los procedimientos constructivos empleados. Así por ejemplo puede apreciarse cómo era la calzada original de madera, cómo fue recuperada la antena caída, cómo se reparó la cámara de anclaje, las etapas de la construcción del pilar oeste, el montaje del tramo central y la prueba de cargas con el puente entero ocupado por camiones para verificar su resistencia. Asimismo se incorporaron imágenes panorámicas del puente en toda su extensión, de su vinculación con la avenida costanera y su relación con la ciudad.

Todas estas fotos, que para un especialista son testimonios valiosos de técnicas y procedimientos poco usuales, y dispa- 


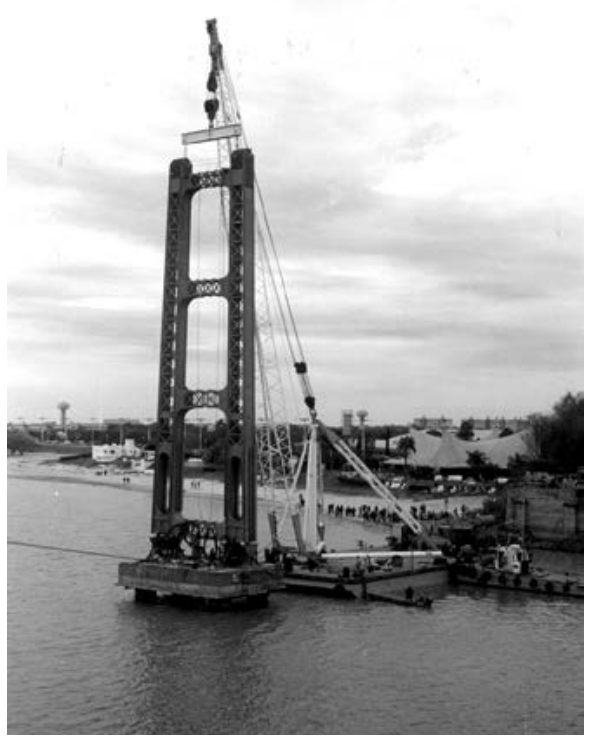

radores para la reflexión sobre el comportamiento de los materiales o la estabilidad de una estructura colgada; para el espectador corriente, son fotos curiosas, que obligan a mirar y volver a mirar para comprender lo que se muestra. Porque, si bien el puente Colgante es conocido por la gran mayoría de los santafesinos, su faceta tecnológica y constructiva no lo es tanto. ¿Cómo se construyó el puente original? ¿Cómo se unieron las partes metálicas en una época en la que no se empleaba la soldadura? ¿Dónde y cómo están anclados los cables que soportan el peso del puente? ¿Cómo se retiró la antena caída? ¿Cómo se trasladó la nueva antena hasta la pila de hormigón ubicada en el medio de la laguna? Éstas son

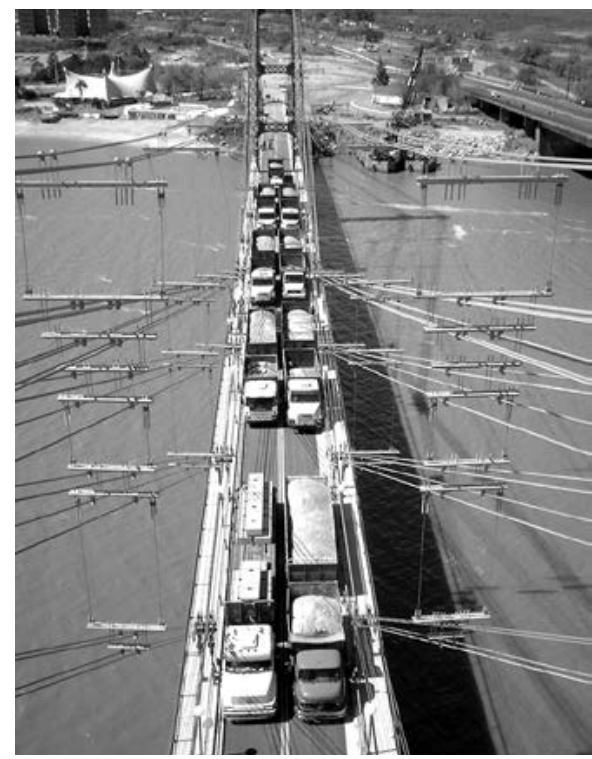

algunas de las preguntas a las cuales esta muestra fotográfica intenta dar respuesta.

El aporte de esta exposición de imágenes del puente Colgante a la historia cultural de la ciudad y a la memoria colectiva es significativa por provenir de un campo, como es el de la ingeniería, desde el cual se abordan aspectos parcialmente explorados en los trabajos previos como son las dimensiones tecnológicas y constructivas de la obra. Por otra parte, a partir de estas fotos es posible observar cómo durante los primeros años la valoración social de la misma estuvo centrada en sus aspectos técnicos convirtiéndose en símbolo de la modernidad y el progreso de la ciudad, y cómo a fines del siglo Xx, tras su caída, la valoración del mismo dejó de estar vin- 

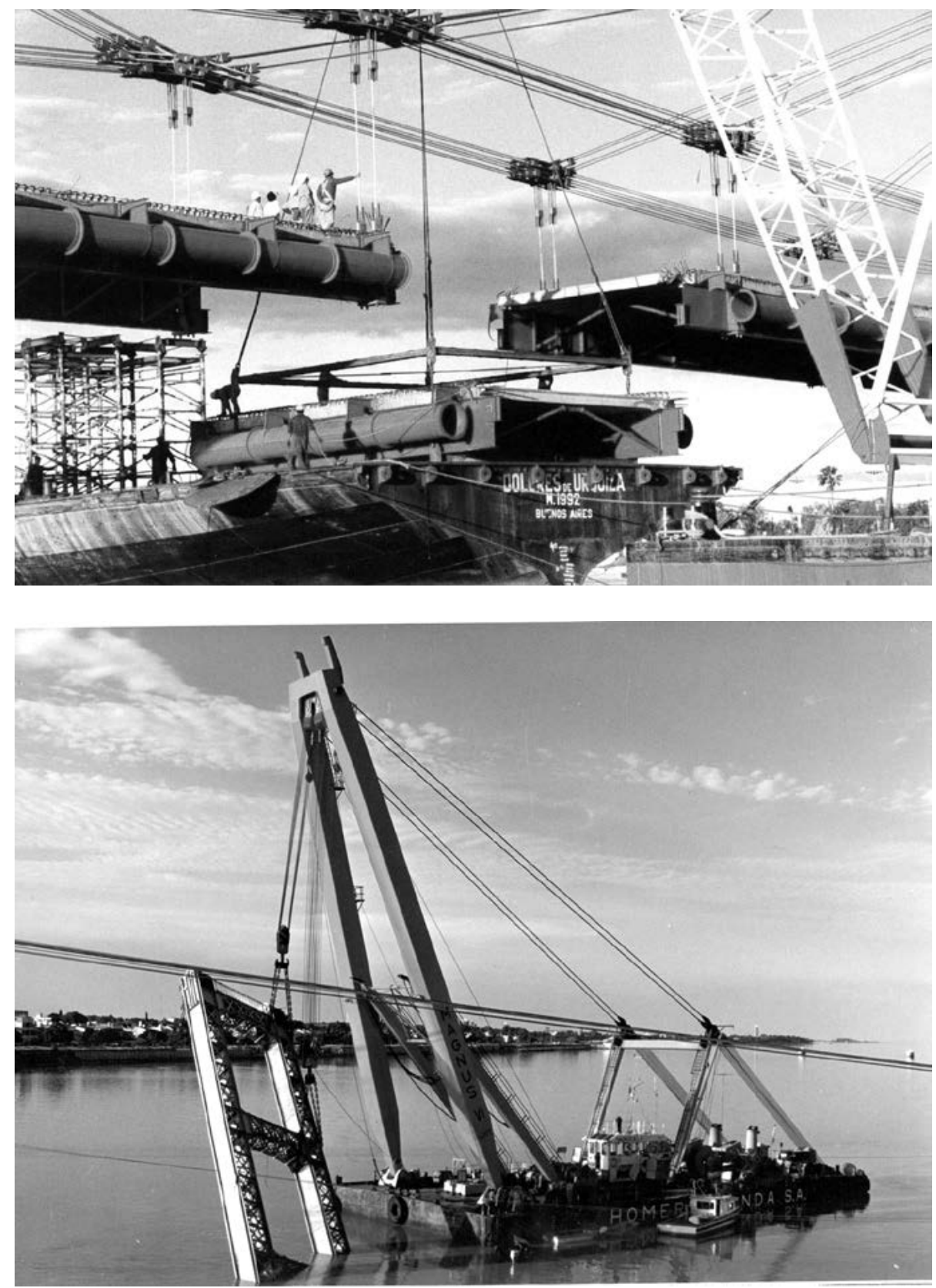
culada a este paradigma moderno cien- de los cambios en el pensamiento produtífico y racional, para pasar a destacar sus cidos por el pasaje de la modernidad a la aspectos históricos y patrimoniales. Esta posmodernidad, y permite explicar cómo reconversión de objeto emblema de lo y por qué una construcción erigida con más nuevo, de lo más avanzado, a objeto un fin puramente utilitario, con el paso símbolo de un pasado y de una identidad, del tiempo, se convirtió en un símbolo da cuenta del impacto en el ámbito local que identifica a toda la ciudad. 
